\author{
Tomasz Skonieczny \\ Zespót Szkót im. Ludzi Morza w Mścicach
}

\title{
Rozwój szkolnictwa podstawowego w gminie Będzino w latach 1945-1954
}

\begin{abstract}
Education on the area of post-war community Będzino (1945-1954)
The article is based on the archives portraying the formation process of Polish schools and cultural institutions as a result of the transformations of the educational system. It presents the condition of the teaching staff and the financial base related to the density of population. The author pays attention to such problems as the lack of staff, funds and equipment. He discusses the forms of co-operation with parents and the society, the participation in all-Polish actions organized by state authorities, especially in the action of fighting illiteracy. The supplement includes the schedule and the curriculum from those times. The article is concluded with the description of the end of the existence of the community of Będzino in its primitive, post-war shape.
\end{abstract}

Keywords: primary education, village, teachers, The People's Republic of Poland

Wraz z końcem II wojny światowej na nadbałtyckie ziemie zaczęli napływać polscy osadnicy. Od 3 do 5 marca 1945 r. Armia Czerwona usunęła z okolic Koszalina armię niemiecką, umożliwiając tym samym tworzenie polskiej, jeszcze tymczasowej, administracji ${ }^{1}$.

Utworzona wtedy w północno-zachodniej części obwodu (od 1946 r. powiatu) koszalińskiego ${ }^{2}$ gmina Będzino o powierzchni 6007 ha obejmowała 12 gromad (do $1954 \mathrm{r}$. jednostek pomocniczych gmin - kompetencjami podobnymi do dzisiejszych sołectw): Złotobrzeg lub Skarbinowo (niem.: Sorenbohm) - dzisiejsze Sarbinowo - wieś i kolonie;

${ }^{1}$ Szerzej na temat początków gminy Będzino zob. T. Skonieczny, „Z powojennych dziejów ówczesnej gminy Będzino (1945-1954)", referat wygłoszony na IX Międzynarodowej Konferencji Dzieje Wsi Pomorskiej w Kłopotowie w 2010 r.

${ }^{2}$ Ziemie te wchodziły w skład okręgu Pomorza Zachodniego (utworzonego 14.03 .1945 r.), od 29.05.1946 województwa szczecińskiego, a od 28.06.1950 r. województwa koszalińskiego. Obecnie jest to województwo zachodniopomorskie, powiat koszaliński. 
Chłopy (Bauerhufen) - wieś oraz Kowale (Kavelsberg); Mielenko (Kl. Möllen) - wieś oraz Komorniki (Feldkaten), Zagaje (Fichtenberg) i Ogrody (Friedrichsruh) - dzisiaj połączone w Zagaje; Bast (Bast) - dzisiejsze Łekno - wieś, Mączno oraz Kazimierz Pomorski (Kasimisburg), Łąkoszyn (Schützenwerder); Będzinko (Neu Banzin) - wieś oraz Barnim (Barning); Skrzeszewo (Schreitstaken); Będzino; Popowo (Poppenhagen) - wieś; Dobre (Todenhagen) - wieś i majątek oraz Pakosław (Pagelsdorf); Cieszyn (Tessin) wieś i majątek; Gniazdowo (Plümenhagen); Komory (Kiefstücken)․ Wielkość poszczególnych gromad była mocno zróżnicowana: od niewielkich Komór i Skrzeszewa po niemalże miasteczko - Sarbinowo (por. mapa i tabela 1).

Dobre ziemie i bliskość miasta sprawiły, że już w 1946 r. prawie wszystkie gospodarstwa, a znajdowało się ich tu przed wojną 529, zasiedlone były przez Polaków a Niemcy wysiedleni. Najwięcej osadników przybyło z powiatu gnieźnieńskiego w ramach tzw. patronatów ${ }^{4}$ oraz z Kresów Wschodnich. Kilka gospodarstw w Sarbinowie objęli osadnicy wojskowi. Po pierwszej fali osadniczej przybyły kolejne, w tym najliczniejsza kielecka. W 1947 r. osiedlono rodziny łemkowskie.

Tabela 1. Populacja gminy Będzino według gromad (ówczesnych jednostek pomocniczych gmin)

\begin{tabular}{|c|c|c|c|}
\hline \multirow{3}{*}{ Miejscowość } & \multicolumn{3}{|c|}{ Liczba mieszkańców } \\
\hline & \multicolumn{2}{|r|}{ w $1952 \mathrm{r}$. } & \multirow{2}{*}{ w $1954 \mathrm{r}$. } \\
\hline & ogółem & $\mathrm{z}$ tego pracujących w rolnictwie & \\
\hline Będzinko & 362 & 60 & 280 \\
\hline Będzino & 370 & 110 & 370 \\
\hline Chłopy & 149 & 27 & 120 \\
\hline Cieszyn & 168 & 107, w tym 102 PGR & $?$ \\
\hline Dobre & 326 & 128, w tym 88 PGR & $?$ \\
\hline Gniazdowo & 199 & 9 & $?$ \\
\hline Komory & 69 & 4 & 80 \\
\hline Lekno & 396 & 158, w tym 103 PGR & 370 \\
\hline Mielenko & 351 & 24 & 370 \\
\hline Popowo & 215 & 21 & 250 \\
\hline Sarbinowo & 560 & 422 & 330 \\
\hline Skrzeszewo & 96 & 8 & 90 \\
\hline
\end{tabular}

Źródło: Archiwum Państwowe w Koszalinie, Prezydium PRN 410, Wykazy ludności pracującej poza rolnictwem w poszczególnych gminach powiatu oraz stan ogólny ludności w gminach.

${ }^{3}$ Archiwum Państwowe w Koszalinie (dalej: AP w Koszalinie), Wydz. Pow. i PRN Koszalin, Spis gmin i gromad pow. koszalińskiego wg nowego podziału administracyjnego z 9.05.1947, k. 59, 61; Mapy topograficzne, przeglądowe i geodezyjne z terenu woj. koszalińskiego, II M. Adm. 50, Województwo szczecińskie, powiat koszaliński, stan z 1947 roku W dalszej części artykułu używam wyłącznie nazw współczesnych.

${ }^{4}$ Por. Z. Dolczewski, A. Kwilecki, Społeczeństwo wielkopolskie w osadnictwie ziem zachodnich, Poznań 1962, s. 35-45. 
Celem artykułu jest ukazanie początków polskiej oświaty na analizowanym terenie. Mimo licznych badań nad powojenną oświatą w Polsce ${ }^{5}$, zwłaszcza w poszczególnych miastach, wciąż jeszcze brakuje szczegółowych opracowań dotyczących szkolnictwa wiejskiego. Dotychczasowe prace koncentrują się na przybliżeniu losów polskiego szkolnictwa w skali powiatu, a nawet województwa koszalińskiego, tym samym oparte są na ogólnych badaniach i wnioskach ${ }^{6}$.

Artykuł powstał przede wszystkim na podstawie źródeł archiwalnych, zgromadzonych w Archiwum Państwowym w Koszalinie oraz dokumentów przechowywanych w pobliskich placówkach. Cezura początkowa artykułu to utworzenie polskiej administracji na analizowanym terenie w 1945 r., zaś końcowa to kres istnienia gminy Będzino w jej pierwotnym, tuż powojennym kształcie, związany z reformą administracyjną kraju z 1954 r. i utworzeniem w miejsce dotychczasowych gmin mniejszych jednostek - gro$\operatorname{mad}^{7}$.

\section{Powstanie polskiego szkolnictwa na obszarze gminy Będzino}

Niemal wraz z pojawieniem się pierwszych polskich osadników na terenie dzisiejszej gminy Będzino (w maju-czerwcu 1945 r.) rozpoczęło się organizowanie polskiego szkolnictwa. Znajdowało się tu dziewięć poniemieckich budynków szkolnych. Początkowo skoncentrowano się na zabezpieczeniu zastanych obiektów oświatowych oraz ich wyposażeniu. Już w czerwcu 1945 r. ${ }^{8}$ dyplomowany nauczyciel Edward Roens ${ }^{9}$ otrzymał no-

\footnotetext{
${ }^{5}$ Por. m.in. K. Trzebiatowski, Oświata i szkolnictwo polskie na Pomorzu Zachodnim w pierwszej połowie XX wieku, Poznań 1961; B. Potyrała, W. Szlufik, Szkolnictwo ogólnoksztatcace na ziemiach zachodnich i pótnocnych $w$ latach 1945-1970, Wrocław 1972; S. Mauersberg, Reforma szkolnictwa w Polsce w latach 1944-1948, Wrocław - Warszawa - Kraków - Gdańsk 1974; B. Potyrała, Szkoła podstawowa w Polsce w latach 1944-1984, Warszawa 1987; L. Szuba, Polityka oświatowa państwa polskiego w latach 1944-1956, Lublin 2002; S. Mauersberg, M. Walczak, Szkolnictwo polskie po drugiej wojnie światowej (1944-1956), Warszawa 2005 .

${ }^{6}$ Por. m.in. T. Szrubka, Szkolnictwo koszalińskie w latach 1945-1968, Poznań-Słupsk 1970; Cz. Plewka, Oświata zachodniopomorska w latach 1945-2002, Szczecin, 2003. W 2009 r. ukazał się artykuł mojego autorstwa (Historia szkolnictwa po 1945 roku na terenie gminy Będzino, w: Gmina Będzino. Z dziejów dawnych i nowych, red. A. Chudziński, Pruszcz Gdański - Będzino 2009, s. 229-243), w zakresie prezentowanych lat będący jednak zaledwie szkicem, a ponadto obejmującym tereny współczesnej gminy Będzino, znacznie od tej, istniejącej w latach 1945-1954 odmiennej. Inne, przywoływane w przypisach prace, odnoszą się do tytułowego zagadnienia w sposób szczątkowy.

${ }^{7}$ Granice współczesnej gminy Będzino ukształtowały się w latach 1972-1975 oraz po korekcie granic z lat 1985 i 2010 z ziem ówczesnej gminy Będzino, Śmiechów, Dobrzyca i części gminy Koszalin.

${ }^{8}$ T. Szrubka, Szkolnictwo w powiecie koszalińskim, w: Podstawowe problemy rozwoju powiatu koszalińskiego w 25-leciu Polski Ludowej, red. E. Z. Zdrojewski, Koszalin 1971, s. 150. E. Cieślak, A. Mroczkowska (Powiat koszaliński, w: Leksykon oświaty zachodniopomorskiej 1945-2005, red. Cz. Plewka, Szczecin, 2005, s. 496) podają datę kwietniową, ale to musi być pomyłka.

${ }^{9}$ Ur. 9.03.1917 w Gnieźnie. Kierownik szkoły w Będzinie w 1. 1945-1950, następnie instruktor w PPRN w Koszalinie, radny Gm. Będzino.
} 
minację $^{10}$ na kierownika Państwowej Szkoły Powszechnej w Będzinie ${ }^{11}$. Mimo okresu wakacyjnego rozpoczęły się już wtedy zajęcia szkolne, aby choć w minimalnym stopniu nadrobić wojenne zaległości. Wkrótce ruszyły kolejne placówki. 4 września Zygmunt Pasławski rozpoczął nauczanie w Gniazdowie ${ }^{12}$, Melania Grodzicka w Sarbinowie ${ }^{13}$, a wkrótce także Zofia Rembalska (po mężu Królikowska) w Łeknie ${ }^{14}$. Możemy tylko się domyślać, że uruchomienie tych placówek miało odpowiednią oprawę, zapewne obecnym na uroczystościach mieszkańcom łzy cisnęły się do oczu zwłaszcza wtedy, gdy uczniowie śpiewali Mazurka Dąbrowskiego czy też Rotę ${ }^{15}$. Trzeba pamiętać, że liczba uczniów była znikoma, np. w Sarbinowie na rozpoczęcie roku zgłosiło się tylko sześcioro dzieci ${ }^{16}$.

Pracę utrudniał brak podręczników, zeszytów, atramentu, kredy. Do pisania wykorzystywano ocalone fragmenty książek oraz poniemieckie druki i zeszyty (często częściowo zapisane), by pisać po ich czystej stronie. Pisano znalezionymi ołówkami, piórami, kredkami $^{17}$. W szkole w Sarbinowie zrobiono tabliczkę mnożenia z liczbami wypisanymi na odwrotnej stronie niemieckiego obrazu ${ }^{18}$. Z początkiem roku szkolnego 1945/46 nauczyciele otrzymali tymczasowe programy nauczania, wzorowane na przedwojennych, jednak z usuniętymi „reakcyjnymi” treściami ${ }^{19}$. Z inspektoratu szkolnego w Koszalinie

${ }^{10}$ W języku polskim i rosyjskim, zapewne o treści: Inspektorat Szkolny w Koszalinie, Deleguję Obywatela... do gminy... jako organizatora szkolnictwa na tamtejszym terenie i upoważniam do wydawania poleceń w zwiazku z zabezpieczeniem majatku szkolnego jak $i$ zaprojektowania przyszłej sieci szkolnej. W zwiazku z powierzonym działem pracy ma obywatel prawo wstępu do obiektów szkolnych oraz budynków nadajacych się do celów szkolnych. Władze wojskowe i cywilne na żadanie winne udzielić wszelkiej pomocy. Inspektor szkolny Górski, Koszalin, dnia... Potwierdzam... Petnomocnik Rzq̨u RP na obwód Koszalin”. AP w Koszalinie, Inspektorat szkolny w Koszalinie, 4, k. 37.

11 Pod taką nazwą szkoły istniały w latach 1945-1946. T. Szrubka, Szkolnictwo w powiecie..., s. 150.

12 Obecnie gmina Biesiekierz - szkoła nieistniejąca.

13 Archiwum Szkoły Podstawowej w Sarbinowie (dalej: ASPwS), Kronika. Obecnie gmina Mielno.

${ }^{14}$ AP w Koszalinie, Inspektorat Szkolny Koszalin, 4, k. 239. Tomasz Szubka (Szkolnictwo w powiecie..., s. 151) wśród uruchomionych wtedy placówek wymienia także szkołę w Sarbinowie, nie udało mi się jednak odnaleźć dokumentu potwierdzającego ten fakt.

15 Por. Wspomnienia Aleksandra Kropidłowskiego, od 1945 r. nauczyciela w Borzytuchomiu, w: G. BojarFijałkowski, M. Prokop, Śladami żotnierskiej drogi (z dziejów ruchu kombatanckiego na ziemi koszalińskiej), Warszawa 1977, s. 315.

16 ASPwS, Kronika.

17 Wywiad z Lucjanem Stefańskim przeprowadzony 16.04.2010 r. przez autora. Por. Wspomnienia Marii Szejd z pracy w Kościenicy, w: Wspomnienia koszalińskich nauczycieli 1945-1946, E. Buczak, A. Czechowicz, „Zapiski Koszalińskie” 1964, nr 1, s. 49; T. Szrubka, Koszalińskie szkolnictwo w pierwszym roku po wyzwoleniu. „Rocznik koszaliński” 1969, nr 5, s.15. A. Kwilecki, Szkoła i nauczyciel na Ziemiach Odzyskanych w okresie pionierskim, „Nowa Szkoła” 1969, nr 8-9.

18 Wywiad z Janem Kowalem przeprowadzony 14.09.2006 r. przez autora.

${ }_{19}$ Plany godzin i materiaty programowe na rok szkolny 1945/46 dla szkót powszechnych i I-ej klasy gimnazjów ogólnokształcacych, Warszawa 1945. Ponadto 18 sierpnia 1945 roku ukazało się zarządzenie o ocenie i używaniu książek szkolnych oraz pomocy naukowych m.in. w szkołach powszechnych. B. Potyrała, Szkoła podstawowa w..., s. 31; W. Chmielewski, Ksztatcenie nauczycieli w okresie ideologizacji szkolnictwa (1944-1956), Warszawa 2006, s. 158. Por. E. J. Kryńska, S. Mauersberg, Indoktrynacja młodzieży szkolnej w Polsce w latach 1945-1956, Białystok 2003, s. 65. 
otrzymano kilka zeszytów do ćwiczeń ortograficznych, które od biedy mogły służyć jako czytanki. Prawdopodobnie nie brakowało tylko ławek ${ }^{20}$. Około października do szkół dotarły pierwsze dzienniki lekcyjne ${ }^{21}$.

W pierwszym powojennym roku szkolnym będzińskie szkoły realizowały program tylko trzech klas ${ }^{22}$. Ponieważ obowiązek szkolny obejmował dzieci w wieku 7-13 lat, ich absolwenci mieli trafiać do szkół zbiorczych w Koszalinie (oddalonego średnio o $15 \mathrm{~km}$ ), ewentualnie w Kołobrzegu $(28 \mathrm{~km})$. Jednak trudności z dojazdem ${ }^{23}$ oraz warunki ekonomiczne powodowały, że zdecydowana większość dzieci kończyła edukację na III, a od 1947 r. - IV klasie ${ }^{24}$. Tylko niewielka część młodzieży podjęła dalszą naukę w Państwowej Szkole Powszechnej nr 1 w Koszalinie ${ }^{25}$.

Kierownicy szkół byli zarazem jedynymi ich pracownikami. Musieli uczyć we wszystkich klasach, co było możliwe przy zmianowym systemie pracy. Prowadzili po 15 godzin w klasach I oraz po 16 w łączonych klasach II i III. Dodatkowo uczniowie kl. III mieli jeszcze 5 godzin samodzielnie: geografię, nauki o przyrodzie i historię. Trudności w nauczaniu potęgowała duża rozbieżność wieku uczniów, gdyż do tej samej klasy trafiali uczniowie w wieku od kilku do kilkunastu lat ${ }^{26}$.

Ówczesna organizacja roku szkolnego przewidywała trzykrotne śródroczne ocenianie uczniów i jedno końcoworoczne, gdyż istniał podział na dwa półrocze i cztery okresy od 1 września do 15 listopada, od 16 listopada do 31 stycznia, od 3 lutego do 15 kwietnia, od 16 kwietnia do 30 czerwca. Wakacje zimowe trwały od 22 grudnia do 2 stycznia. Wakacje wielkanocne trwały od wielkanocnego czwartku do środy poświątecznej włącznie ${ }^{27}$.

Pierwszy okres budowy polskiej oświaty na analizowanym obszarze zakończył się połowicznym sukcesem. Udało się stosunkowo szybko uruchomić dwie szkoły podstawowe, choć ze względu na braki kadrowe zaledwie czteroklasowe.

\footnotetext{
${ }^{20}$ W każdym bądź razie ławki były w 1950 r., podczas gdy w sąsiedniej Dobrzycy czy Mielnie ciagle były braki w tym zakresie. AP w Koszalinie, Inspektorat szkolny Koszalin 1, Zestawienie danych liczbowych z projektów organizacyjnych $1950 \mathrm{r}$.

${ }^{21}$ Cz. Plewka, Oświata zachodniopomorska w latach 1945-2002. O ideach i praktykach edukacyjnych. Szczecin 2003, s. 48.

22 E. Cieślak, A. Mroczkowska, Powiat koszaliński..., s. 496-497.

${ }^{23}$ Kursował $\mathrm{i}$ to nieregularnie pociąg zatrzymujący się w Kazimierzu Pomorskim i Będzinie - bywało jednak, że zimą z powodu braku opału nie mógł jechać. Wtedy maszyniści przy pomocy pasażerów rąbali i zbierali drewno. Wspomnienia Jana Szachnowskiego, zebrane i spisane przez Adę Gacką (w zbiorach autora).

${ }^{24}$ Leksykon oświaty..., s. 108.

${ }^{25}$ M. Stachowska, Transport i łaczność, w: Podstawowe problemy rozwoju..., s. 118.

${ }^{26}$ Por. M. Praczuk, Poczatki szkolnictwa w 1945 roku, „Zapiski Koszalińskie” 1963, nr 3, s. 78-79; T. Szrubka, Szkolnictwo koszalińskie w..., s. 13; Cz. Plewka, Oświata zachodniopomorska w..., s. 24. Por. T. Skonieczny, Z dziejów szkolnictwa polskiego w Mścicach 1945-2006, Mścice 2006, tabela 3, s. 13.

${ }^{27}$ Cz. Plewka, Oświata zachodniopomorska w..., s. 48.
} 


\section{Rozwój szkolnictwa}

$\mathrm{W}$ roku szkolnym jednym z celów reformy było podniesienie stopnia organizacji szkół - z trzyklasowych na czteroklasowe przy jednoczesnej zmianie nazw placówek na: publiczne szkoły powszechne ${ }^{28}$. Inspektorat Szkolny w Koszalinie zwiększył obsadę do dwóch nauczycieli: do Sarbinowa skierowano Stefanię Szocińską a do Gniazdowa Janinę Jabłońską. Umożliwiło to zorganizowanie w tych miejscowościach klas V i VI. Kontynuowano odchodzenie od przedwojennych programów nauczania, wprowadzając nowe, „postępowe” treści ${ }^{29}$. Uruchomiono nową placówkę - Elżbieta Piechocka została kierownikiem szkoły w Dobrym.

Nadal wszystkie szkoły pracowały w systemie zmianowym, w klasach łączonych ${ }^{30}$. Najczęściej uczniowie z klas III i IV mieli zajęcia od $8^{00}$ do $11^{130}$, I i II od $11^{45}$ do $13^{30}$. Ponieważ nie można było zorganizować zastępstw, dużo lekcji przepadało z powodu różnych uroczystości, zebrań i szkoleń bądź chorób nauczycieli ${ }^{31}$. Pojawily się, zapewne jeszcze pojedyncze egzemplarze elementarza. Nadal jednak istotny problem stanowił brak pomocy naukowych, które musiano wykonywać we własnym zakresie.

Początek roku szkolnego 1947/48 zapowiadał daleko idące zmiany. Minister Oświaty Stanisław Skrzeszewski zapowiadał Nie może i nie będzie miejsca w naszej szkole dla wrogów naszego demokratycznego państwa [...] dla wrogów świadomie lub nieświadomie działajacych. [...] Czasy bezkarności się skończyly³2. W efekcie na analizowanym terenie, podobnie jak i w całym kraju, doszło do licznych zmian w kadrze nauczycielskiej (zob. tabela 3). Na stanowisku pozostał tylko kierownik szkoły w Będzinie, aktywny członek PPR Wiktor Hybza oraz w Sarbinowie nauczycielka Stefania Szopińska. Skorygowano sieć szkół: likwidacji uległa szkoła w Gniazdowie, uruchomiono nową w Popowie. Jej pierwszą kierowniczką została Władysława Stawicka. Wypowiedź ta oznaczała także zmierzch przedwojennych metod wychowawczych i programów nauczania. Należało wzorować się na osiaggnięciach radzieckich pedagogów i kształtować: naukowy światopogląd, moralność socjalistyczną, wychowanie w kolektywie, patriotyzm ludowy, internacjonalizm i rozwijać kształcenie politechniczne ${ }^{33}$. Można to także potrak-

${ }^{28}$ Nazwa ta obowiązywała do 1948 r. Szeroko o zamierzonych i wprowadzonych reformach oświaty zob.: S. Mauersberg, Reforma szkolnictwa w....

${ }_{29}$ Zob. Plany godzin i programy przejściowe na rok szkolny 1946/47 dla szkót powszechnych, Warszawa 1946. Zmiany dotyczyły szczególnie treści realizowanych w klasach VI-VII. Zob. B. Potyrała, Szkoła Podstawowa $w \ldots$, s. 35-37.

${ }^{30}$ AP w Koszalinie, Inspektorat szkolny w Koszalinie, 5, Spis rejonów płatniczych (nauczyciele publicznych szkół i przedszkoli), 5.10.1946, k. 1-78.

31 Por. T. Skonieczny, Z dziejów szkolnictwa ..., s. 12.

32 S. Skrzeszewski, Przemówienie do nauczycielstwa z okazji nowego roku szkolnego wygłoszone 3 września 1947 roku (przemówienie radiowe), „Nowa Szkoła” 1947, nr 2-3; za: R. Fudali, Heteronomiczny charakter ról społecznych nauczycieli w warunkach ustroju totalitarnego w Polsce 1945-1989, za: www.pedagog. uw.edu.pl/THE/Fudali.pdf (16.03.2010). Por. Dz. Urz. Min. Oświaty 1947, nr 12, poz. 286, Instrukcja w dnia 7 października 1947 w prawie realizacji „Zagadnień społeczno-wychowawczych”.

33 B. Potyrała, Oświata w Polsce w latach 1949-1956, Wrocław 1992, s. 8. 
tować jako zapowiedź stopniowego wycofywania religii ze szkół. Dotychczas nie tylko swobodnie prowadzono jej nauczania w wymiarze 2 godzin tygodniowo, modlono się przed i po lekcjach, organizowano 3-dniowe rekolekcje wielkopostne wolne od zajęć szkolnych oraz dodatkowe 3 dni na gremialne przystąpienie do sakramentów świę$\operatorname{tych}^{34}$.

Tabela 2. Siatka zajęć lekcyjnych w roku szkolnym 1946/47

\begin{tabular}{|c|c|c|}
\hline Przedmioty & I-II & III-IV \\
\hline Religia & 2 & 2 \\
\hline J. polski & 6 & 6 \\
\hline Historia & - & 1 \\
\hline Matematyka & 4 & 4 \\
\hline Rysunek & 0,5 & 1 \\
\hline Prace ręczne & 0,5 & 1 \\
\hline Śpiew & 1 & 1 \\
\hline W.f. & 1 & 1 \\
\hline Geografia i przyroda & & 4 \\
\hline Razem & 15 & 21 \\
\hline
\end{tabular}

Źródło: Archiwum Zespołu Szkół im. Ludzi Morza w Mścicach; T. Skonieczny, Z dziejów szkolnictwa polskiego w Mścicach 1945-2006, Mścice 2006, s. 12.

Początek roku szkolnego 1948/1949 to ponowna zmiana nazw placówek na: publiczne szkoły podstawowe ${ }^{35}$. Decyzja władz państwowych o wprowadzeniu jednolitej szkoły 11-letniej, w skład której miała wejść 7-letnia szkoła podstawowa i 4-letnie liceum ogólnokształcące nie miała większego znaczenia dla analizowanego terenu, gdyż problemy napotykano nawet z utworzeniem pełnych szkół podstawowych. Dopiero wiosną $1949 \mathrm{r}$. dzięki przeniesieniu do zaadaptowanego i świeżo wyremontowanego większego budynku szkoły w Sarbinowie możliwe stało się uruchomienie z początkiem nowego roku szkolnego VII klasy. Dzięki temu stała się szkołą zbiorczą dla absolwentów niepełnych szkół podstawowych w Będzinie i w Łeknie. Wydatnie poprawiło to możliwości edukacyjne mieszkańcom gminy, bo dotychczas obowiązkiem szkolnym objętych było tylko 250 spośród 480 dzieci w wieku szkolnym ${ }^{36}$, gdyż aż do tego momentu pełne wykształcenie podstawowe można było uzyskać w szkole w Mielnie (w gminie Koszalin), gdzie uczęsz-

\footnotetext{
34 W. Chmielewski, Ksztatcenie nauczycieli w..., s. 230, 249.

35 DzUrzMO 1948, nr 7, poz. 127, za: B. Potyrała, Szkoła Podstawowa..., s. 98.

36 AP w Koszalinie, Gm. Będzino 15, Budżet administracyjny na rok 1948, k. 3.
} 


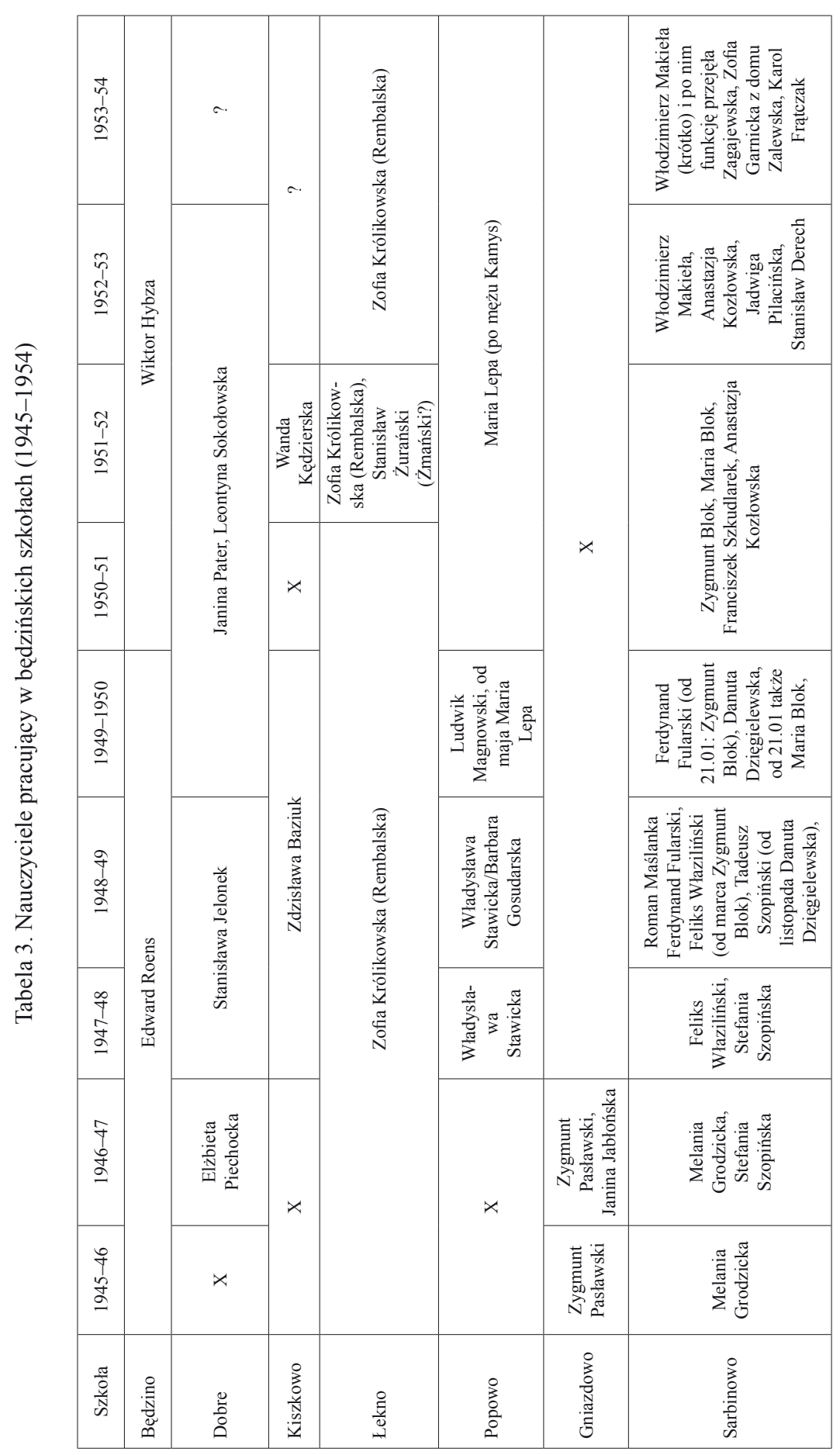

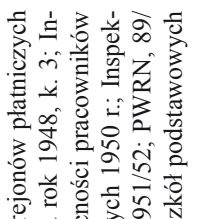

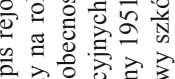

n

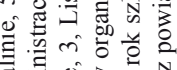

可

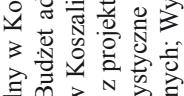

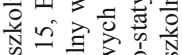

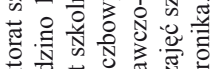

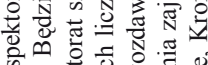

ต.

人ิ)

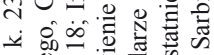

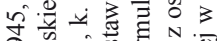

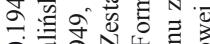

으의

तु

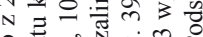

ㅇ. हो

年

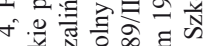

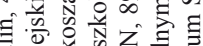

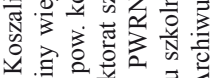
. 긍 3 윰

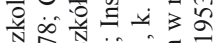

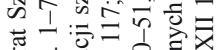

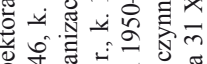

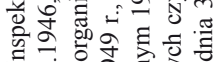

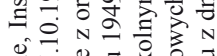

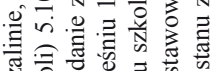
政

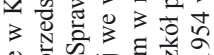
o क क ज

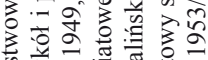

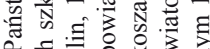

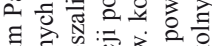

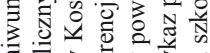

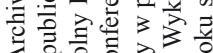

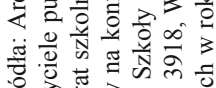
资

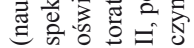


czała część młodzieży z Łekna oraz w Parnowie w gminie Biesiekierz, gdzie uczęszczali absolwenci czteroklasowych szkół z Dobrego i Popowa ${ }^{37}$.

Uruchomienie VII klasy w szkole w Sarbinowie możliwe stało się także dzięki zwiększeniu zatrudnienia do czterech nauczycieli. Uczono na dwie zmiany: w godz. $8^{00}-11^{40}$ i od $11^{50}$ do $13^{30-1} 4^{30}$. Każdy z nauczycieli uczył jedną klasę młodszą oraz różnych przedmiotów w klasach starszych. Przydziały przedmiotów zmieniały się w zależności od potrzeb szkoły. Klasa V była najliczniejsza, ponieważ dochodzili do niej uczniowie z pozostałych placówek. W klasach VI i VII uczniów już było mniej, ponieważ wraz z osiągnięciem wieku 13 lat, kończącego obowiązek nauki, wielu, zwłaszcza spoza Sarbinowa rezygnowało z dalszej nauki (zob. tabela 5).

Od roku szkolnego 1950/51 nastąpiła zmiana nazw na: szkoły ogólnokształcące stopnia podstawowego. W klasie I po raz pierwszy zastosowano wtedy ocenianie bez stopni. Zaczynały się czasy radości i dumy z osiagnięć Polski Ludowej. Miano cieszyć się z imponujacych wyników nowego budownictwa socjalistycznego, które władza ludowa osiągnęła dzięki bohaterskiej postawie klasy robotniczej i rosnacej coraz bardziej jedności naszego narodu $w$ walce o pokój $i$ plan 6-letni ${ }^{38}$. Plan pracy szkoły zakładał przeprowadzenie egzaminów końcowych dla uczniów klas VII z języka polskiego, matematyki i biologii, które pierwszy raz odbyły się w czerwcu 1952 r. w Sarbinowie. O ukończeniu szkoły decydowały wyniki egzaminów oraz stopnie końcoworoczne z poszczególnych przedmiotów. Dla siódmoklasistów, którzy nie uzyskali pozytywnych ocen egzaminacyjnych przewidywano przeprowadzenie egzaminów poprawkowych ${ }^{39}$. Stopniowe zatrudnianie dodatkowych nauczycieli pozwoliło na utworzenie wyższych klas: klas V-VI w Dobrym i Łeknie (zob. tabela 3).

W kolejnym roku szkolnym wszystkie szkoły i zakłady wychowawczo-opiekuńcze oraz placówki pracy pozaszkolnej w Polsce powinny tak zorganizować pracę dydaktyczną i wychowawczą, aby każdy uczeń był przodownikiem najszlachetniejszych idei społecznych, idei socjalizmu, aby znat plan 6-letni i program budownictwa socjalizmu, aby stat sie jego oddanym i ofiarnym realizatorem, a tym samym niestrudzonym bojownikiem o pokój ${ }^{40}$. Ustalono wtedy dzisiejszą nazwę placówek ${ }^{41}$. Od 1953 r. uczniowie V klasy obowiązkowo brali udział w lekcjach języka rosyjskiego ${ }^{42}$.

Dla nauczycieli organizowano przymusowe szkolenia ideologiczne. Stałym punktem były tzw. konferencje sierpniowe. Ponadto organizowano nadzwyczajne spotkania. O ich przebiegu świadczy zachowany protokół z przebiegu konferencji w związku z mianowaniem 7 listopada 1949 r. nowego Marszałka Polski Konstantego Rokossowskiego zorga-

\footnotetext{
${ }^{37}$ Do końca istnienia gminy Będzino w pierwotnym kształcie sytuacja nie uległa poprawie. Szkoła w Łeknie stała się VII klasową dopiero w 1957 roku.

38 L. Szuba, Polityka oświatowa państwa polskiego w latach 1944-1956, Lublin 2002, s. 190.

39 Por. Pót wieku jedenastki 1954-2004, Koszalin 2004, s. 11.

40 L. Szuba, Polityka oświatowa państwa..., s. 201.

${ }^{41}$ DzUrzMO 1952, nr 14, poz.111, Zarządzenie Ministra Oświaty z dnia 21.08.1952 w sprawie nazw szkół ogólnokształcących.

${ }^{42}$ K. Kosiński, Oficjalne i prywatne życie młodzieży w czasach PRL, Warszawa 2006, s. 28.
} 
nizowano dla wszystkich nauczycieli obowiązkowe konferencje. Będzińscy nauczycieli wzięli udział w szkoleniu w Dobrzycy. Wygłoszona tam została prelekcja przez Monikę Dąbrowską, nauczycielkę Szkoły Podstawowej nr 1 w Koszalinie. Prelegentka obszernie zreferowała Jego życiorys oraz działalność. Charakteryzujac postać Marszatka Rokosowskiego, odmalowała dzieciństwo, jego późniejsze borykanie się z trudnościami zwiqzanymi z utrzymaniem się. Przedstawiła Go jako czynnego rewolucjoniste już w młodości, nie uginajacego się przed represjami ówczesnych rzqdów kapitalistycznych. Nakreśliła działalność Jego w pierwszej i drugiej wojnie światowej, a w szczególności czyny, przez które stał się znanym ogółowi społeczeństwa polskiego w czasie tej ostatniej. Protokołowała Dąbrowska Monika, czyli sama prowadząca spotkanie ${ }^{43}$. Władze obawiały się niszczenia w szkołach ilustracji z podobizną Marszałka lub zdarcia gazetki szkolnej z wiadomością o jego nominacji, nic takiego na analizowanym terenie jednak nie odnotowano ${ }^{44}$.

Lata 1946-1954 to postępująca ideologizacja szkolnictwa, zwłaszcza w sferze programowej. Mimo to ze względu na rozbudowę sieci szkolnej i umożliwienie realizacji obowiązku szkolnego prawie wszystkim dzieciom, okres ten należy ocenić pozytywnie.

Tabela 4. Wybrane dane statystyczne dotyczące szkolnictwa gminy Będzino

\begin{tabular}{|c|c|c|c|c|c|c|c|c|c|c|c|c|}
\hline \multirow[b]{2}{*}{$\begin{array}{c}\text { Nazwa } \\
\text { szkoły } \\
\text { (okres } \\
\text { działalno- } \\
\text { ści) }\end{array}$} & \multicolumn{2}{|c|}{10.09 .1949} & \multicolumn{5}{|c|}{5.05 .1950} & \multicolumn{4}{|c|}{1952} & \multirow[b]{2}{*}{ 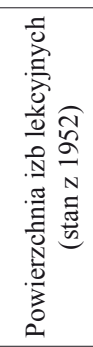 } \\
\hline & 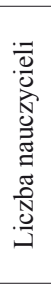 & 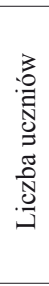 & 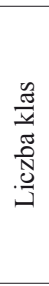 & 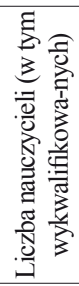 & 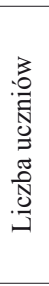 & 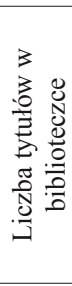 & 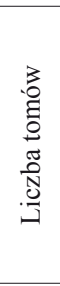 & 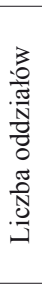 & 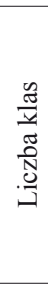 & 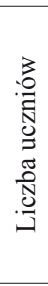 & 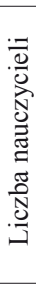 & \\
\hline Będzino & 1 & 34 & IV & $1(1)$ & 30 & 43 & 52 & 2 & IV & 32 & 1 & 40 \\
\hline Dobre & 2 & 61 & VI & $2(0)$ & 56 & 136 & 136 & 3 & VI & 58 & 2 & $54 \mathrm{i} 48$ \\
\hline Łekno & 1 & 32 & IV & $1(1)$ & 35 & 53 & 53 & 3 & VI & 50 & 2 & 54,60 \\
\hline Popowo & 1 & 21 & IV & $1(0)$ & 21 & 28 & 28 & 2 & IV & 12 & 1 & 20 \\
\hline Sarbinowo & 3 & 32 & VII & $3(1)$ & 99 & 158 & 158 & 7 & VII & 100 & 3 & 4 izby \\
\hline
\end{tabular}

${ }^{43}$ AP w Koszalinie, Inspektorat szkolny w Koszalinie 3, Protokół z odprawy nauczycieli gminy Koszalin, k. $145-146$.

44 Ibidem. 
Źródło: Archiwum Państwowe w Koszalinie, Gminy wiejskie powiatu koszalińskiego, Gmina Będzino 15, Budżet administracyjny na rok 1948, k. 3; Inspektorat szkolny Koszalin 1, Sprawozdanie z organizacji szkól w pow. koszalińskim, 10.9.1949, k. 18, Szkoły w pow. koszalińskim w roku szkolnym 1950-51, k. 89; Zestawienie danych liczbowych z projektów organizacyjnych $1950 \mathrm{r}$.

Tabela 5. Pracownicy i uczniowie szkół podstawowych w gminie Będzino w roku szkolnym $1951-1952$

\begin{tabular}{|c|c|c|c|c|c|c|c|c|c|c|c|c|}
\hline \multirow[b]{3}{*}{ Szkoła } & \multicolumn{3}{|c|}{ Pracownicy } & \multicolumn{9}{|c|}{ Uczniów } \\
\hline & \multirow[b]{2}{*}{ 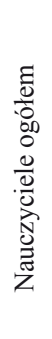 } & \multirow[b]{2}{*}{ 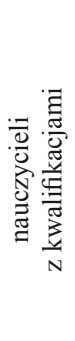 } & \multirow[b]{2}{*}{ 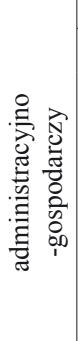 } & \multicolumn{8}{|c|}{ w klasie (szkoła zbiorcza) } & \multirow[b]{2}{*}{ 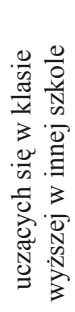 } \\
\hline & & & & 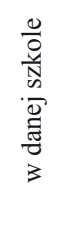 & I & II & III & IV & V & VI & VII & \\
\hline Będzino & 1 & & 1 & 33 & 11 & 12 & 5 & 2 & \multicolumn{3}{|c|}{ Sarbinowo } & 6 \\
\hline Popowo & 1 & 1 & 1 & 19 & 5 & 2 & 5 & 7 & \multicolumn{3}{|c|}{ Parnowo } & 13 \\
\hline Dobre & 2 & & 1 & 59 & 6 & 16 & 8 & 9 & 9 & 11 & Parnowo & 6 \\
\hline Łekno & 2 & 2 & 1 & 63 & 8 & 7 & 9 & 11 & 11 & 17 & $\begin{array}{l}\text { Mielno lub } \\
\text { Sarbinowo }\end{array}$ & 5 \\
\hline Sarbinowo & 3 & 1 & 1 & 125 & 11 & 12 & 14 & 11 & 39 & 22 & 16 & 14 \\
\hline
\end{tabular}

Źródło: Archiwum Państwowe w Koszalinie, Prezydium WRN 3863, Wykaz powiatowy szkół czynnych w roku szkolnym 1951-52.

\section{Baza materialna szkół podstawowych}

Choć zatrudnianie nauczycieli, budowa szkół i ich remonty generalne były w gestii Inspektoratu Szkolnego (Oświaty) w Koszalinie, to szkolne budynki ${ }^{45}$ oraz bieżące utrzymanie infrastruktury należało do władz gminnych. Mimo szczerych chęci ciągle jednak brakowało środków na utrzymanie placówek i remonty bieżące ${ }^{46}$. Były one konieczne, gdyż budynki szkolne pełniły funkcję placówek oświatowej od czasów przedwojennych. Budowane były w latach trzydziestych XX w. Składały się z jednej (Będzino i Popowo)

45 Por. DzURP1946, nr 13, poz. 87, Dekret z 8 marca 1946 o majątkach opuszczonych i poniemieckich, art. 2, pkt 4 .

${ }^{46} \mathrm{~Np}$. w 1951 r. szkoły wymagały natychmiastowego remontu. Władze gminy prosiły PRN w Koszalinie o kredyt na ten cel. AP w Koszalinie, Gm. Będzino 8, Protokół z sesji GRN z dnia 14.06.1951, k. 42. 
lub dwu izb lekcyjnych o drewnianych podłogach (Łekno, Dobre, Gniazdowo i początkowo, do wiosny 1949 r. także Sarbinowo) wysokich na ok. 3,20 m), mieszkania nauczycielskiego i zabudowań gospodarczych ${ }^{47}$. Nigdzie nie było sal gimnastycznych. Lekcje gimnastyki (wychowania fizycznego) nauczyciele prowadzili na podwórkach, zimą i w czasie niepogody w izbach lekcyjnych, po złożeniu przez dzieci ławek. Szkoła w Łeknie znajdowała się bezpośrednio przy dość ruchliwej drodze (dziś krajowej 11) ${ }^{48}$.

Ich stan musiał być nie najlepszy, gdyż przykładowo w 1949 r. na 5 szkół istniejących w ówczesnej gminie Będzino - we wszystkich dokonano modernizacji: w szkole Będzino przestawiono piece i odmalowano ściany, podobnie w Łeknie, a ponadto naprawiono dach, w Dobrym odmalowano ściany i naprawiono dach, w Popowie odmalowano ściany i naprawiono podłogi, szkołę Sarbinowo - przeniesiono do zaadaptowanego, większego budynku oddalonego o ok. $100 \mathrm{~m}^{49}$, o 4 izbach lekcyjnych i dwóch mieszkaniach nauczycielskich. Budynek ten był piętrowy, otynkowany ${ }^{50}$. Od wiosny 1949 r. w gminie dysponowano 10 salami lekcyjnymi wyposażonymi w 16 pieców kaflowych ${ }^{51}$.

Budynki były zelektryfikowane (choć np. w Dobrym uruchomiono szkołę we wrześniu 1947, prąd doprowadzono zaś w listopadzie), ogrzewanie stanowiły piece kaflowe, przeznaczone do spalania węgla, którego notorycznie brakowało i stąd palono drewnem, często pozyskiwanym z rozbiórek (zwłaszcza w 1954 r.), a nawet torfem. Brakowało boisk, istniały raczej place apelowe. Tereny wokół szkół nigdzie nie były ogrodzone ${ }^{52}$.

Sanitariaty znajdowały się na zewnątrz budynków - były to budki z 2-4 otworami w ziemi. W budynkach szkół dysponowano zlewem i miską do mycia rąk. Wodę pompowano z pobliskich studni. Duże przeobrażenia na początku lat pięćdziesiątych przeszła szkoła w Sarbinowie. Doprowadzono do niej wodociąg, urządzono profesjonalne boisko do gry w szczypiorniaka (piłkę ręczna). Wcześniej dysponowano tylko małym placykiem po wyciętym poniemieckim sadzie owocowym ${ }^{53}$. Przy każdej szkole istniał ogródek warzywny i kwiatowy ${ }^{54}$.

Wyposażenie pobliskiej szkoły w Mścicach 1 października 1947 stanowiły: 2 tablice szkolne, 5 szaf, 4 stoły, 5 krzeseł, 19 dwu- i trzyosobowych ławek, 1 mapa ścienna Polski, 1 mapa Europy ${ }^{55}$. Zapewne podobne wyposażenie znajdowało się i w analizowanych placówkach. Ówczesne ławki szkolne były drewniane, pośrodku z otworem na kałamarz

\footnotetext{
47 Por. Tabela nr 4. k. 46 .

${ }^{48}$ AP w Koszalinie Prezydium GRN w Będzinie 2, Protokół z posiedzenia GRN z dnia 13.07.1958,

49 AP w Koszalinie, Gm, Będzino 5, Sprawozdanie wójta gminy z działalności za czas od 1.01.1949 do 31.12.1949, k. 7.

${ }^{50}$ Wywiad z Karolem Frątczakiem przeprowadzony 12.06.2010 r. przez autora. Obecnie jest budynkiem wyłącznie mieszkalnym.

51 AP w Koszalinie, Gm. Będzino 15, Budżet administracyjny na rok 1948, k. 3.

52 Materiał fotograficzny analizowanych placówek.

53 Wywiad z Karolem Frątczakiem przeprowadzony 12.06.2010 r. przez autora.

${ }^{54}$ Por. AP w Koszalinie, Gm. Dobrzyca 7, Pismo z 31.04.1949, k. 3.

55 Archiwum Szkoły Podstawowej w Mścicach, Księga inwentarzowa.
} 
i zagłębieniami na położenie pióra. Dekoracje ścian stanowiły zapewne gazetki ścienne (wycinki z prasy), czarno-białe portrety przywódców, godło, do roku 1949 krzyż ${ }^{56}$.

3 marca 1947 r. kierownik szkoły w Będzinie Edward Roens wypożyczył tzw. komplet 40 książek z Powiatowej Biblioteki Publicznej w Koszalinie, tworząc w szkole Punkt Biblioteczny. W pierwszym okresie działalności odwiedzało go 39 dorosłych czytelników. Obowiązkiem kierownika punktu było zachęcanie do czytania, odnotowywanie wypożyczeń, odbieranie książek od czytelników zalegających z oddawaniem oraz co półroczne wymienianie kompletu książek w bibliotece koszalińskiej57.

Stopniowo takie punkty udało się uruchomić we wszystkich szkołach, choć z bardzo nielicznymi księgozbiorami. Niestety niewielu uczniów początkowo z nich korzystało. Szczególnym zainteresowaniem cieszyły się zapewne: Kamizelka i Placówka - Bolesława Prusa; Janko Muzykant - Henryka Sienkiewicza; ABC - Elizy Orzeszkowej ${ }^{58}$. Mimo że dbano o wyposażenie biblioteki szkolnej w klasyków marksizmu: Marksa i Lenina oraz książki propagujące zagadnienia społeczne, pozycje te zapewne nie cieszyły się wielkim wzięciem ${ }^{59}$.

Szczególnym wydarzeniem było otrzymanie w styczniu 1949 r. w odpowiedzi na akcję Ministra Oświaty ${ }^{60}$, radioodbiorników przez szkoły w Sarbinowie, Będzinie i Dobrym $^{61}$. Muszę jednak podkreślić, że był to incydentalny przypadek. Ówczesne nakłady inwestycyjne na rozwój materialny szkół praktycznie nie istniały. Wzrosły dopiero w drugiej połowie lat pięćdziesiątych XX w., co uwidoczniło się w zakupach pomocy naukowych i szaf do ich przechowywania.

Reasumując, baza materialna jak na ówczesne powojenne warunki była stosunkowo dobra - wszystkie budynki były murowane (co wcale nie było takie oczywiste we wsiach tzw. Polski Centralnej), stopniowo remontowane i wyposażane.

\section{Dzialalność pozalekcyjna}

Szkoły postrzegane od zawsze były jako często jedyne placówki kulturalne na wsi. Sprzyjało to współpracy mieszkańców z nauczycielami. Było to szczególnie ważne w pierwszych, powojennych latach. Położenie gminy Będzino, stosunkowo blisko „dużych” miast Kołobrzegu i Koszalina, czynna linia kolejowa i niezłe zabudowania spowodowały, że w porównaniu z innymi gminami na Pomorzu Zachodnim nie było aż takich

56 Szerzej zob. K. Kosiński, Oficjalne i prywatne..., s. 189-193.

57 Gminna Biblioteka Publiczna w Będzinie, Kronika.

58 Wywiad z Lucjanem Stefańskim przeprowadzony 16.04.2010 r. przez autora.

59 Por. T. Skonieczny, Z dziejów szkolnictwa..., s. 24.

${ }^{60}$ Już 4 czerwca 1948 roku Minister Oświaty zalecał zbieranie koniecznych funduszy na zaopatrzeniu możliwie największej liczby szkół w radioaparaty i urządzenia głośnikowe. DzUrzMO 1948, nr 9, poz. 163, s. 427.

${ }^{61}$ AP w Koszalinie, Gm. Będzino 5, Sprawozdanie wójta gminy z działalności za czas od 1.01.1949 do 31.12.1949, k. 7. 
kłopotów z chętnymi do podjęcia pracy w zawodzie nauczyciela ${ }^{62}$. Brakowało jednak osób z odpowiednimi kwalifikacjami, gdyż okupanci ze szczególną zajadłością eksterminowali właśnie nauczycieli, uznając ich za „nośnik” polskiej kultury, mowy i przetrwania polskości. W wyniku II wojny światowej stan kadry nauczycielskiej zmniejszył się o 20 tys., tj. o ponad $26 \%{ }^{63}$. Ponadto warunki ekonomiczne i socjalne nie zachęcały nikogo szczególnie do podjęcia pracy na wsi, gdzie trudno było dojechać ${ }^{64}$. W roku 1945, a nierzadko także w 1946 nauczyciele byli praktycznie bez środków do życia. Nie było ustalonych wynagrodzeń, a więc nie były one wypłacane ${ }^{65}$. Ze wspomnień nauczyciela, który w 1945 r. rozpoczął pracę w pobliżu Będzina wynika, że ludność wsi, gdzie był kierownikiem szkoły, „opodatkowała się” dobrowolnie na jego rzecz. Chłopi postanowili przeznaczyć na ten cel po kilka kilogramów żyta z hektara ${ }^{66}$. Płace nauczycieli (pobory wypłacano dwa razy w miesiącu, płatnicy rejonowi - w ówczesnej gminie Będzinie kierownik miejscowej placówki Edward Roens - przyjeżdżali po pieniądze do Inspektoratu Szkolnego w Koszalinie) nie zmieniały się przez wiele lat, nauczyciele zarabiali średnio 1/3-1/4 tego, co powinno im wystarczyć, aby się utrzymać ${ }^{67}$. Ten niekorzystny fakt miał wpływ na płynność kadr w szkole, na frustrację nauczycieli i ich niechęć do angażowania się w sprawy oświaty. Trudną czyniły ją także, początkowo nawet coroczne przeniesienia służbowe (zob. tabela 3), niestabilne stosunki służbowe, obowiązek upolityczniania lekcji, przestarzałe metody pracy, brak nowatorstwa ${ }^{68}$. Aż do połowy lat pięćdziesiątych nie było też żadnych ogólnopolskich uregulowań prawnych, normujących prawa i obowiązki nauczycieli. Zmuszało to do nagminnego zatrudniania nauczycieli niewykwalifikowanych. Na terenie współczesnej gminy Będzino jeszcze w roku szkolnym 1950/51 na 22 zatrudnionych nauczycieli tylko 7 miało kwalifikacje ${ }^{69}$.

${ }^{62}$ Por. Cz. Plewka, Oświata zachodniopomorska w..., s. 46.

${ }^{63}$ W. Wojdyński, O kształceniu nauczycieli Szkoły Podstawowej w Polsce i świecie, Warszawa 1971, s. 96. Wpływ na ten stan miał także fakt, że w okresie wojny nie odbywało się kształcenie nowych nauczycieli.

${ }^{64}$ Np. mianowany 2.08.1945 kierownikiem szkoły w sąsiednim Śmiechowie Kazimierz Zabłocki - zrezygnował ze stanowiska. AP w Koszalinie, Inspektorat Szkolny Koszalin, 4, k. 239.

${ }^{65}$ A. Kwilecki, Rola społeczna nauczyciela na Ziemiach Zachodnich, Poznań, 1960, s. 55. Symptomatyczne jest tu pismo z 10 lipca 1946 roku: „Stosownie do okólników w sprawie rekrutacji młodzieży do szkół pedagogicznych [do Państwowego Liceum Pedagogicznego w Słupsku] kierownictwa szkół prowadziły akcję propagandową. Niestety młodzież jest w większości przypadków niezdecydowana z powodu negatywnego ustosunkowywania się rodziców do zawodu nauczycielskiego. Ich zdaniem nie może być mowy o zapełnieniu zakładów kształcenia nauczycieli wartościowym elementem do chwili, gdy sytuacja materialna nauczycielstwa nie ulegnie znacznej poprawie.” AP w Koszalinie, Inspektorat oświaty w Koszalinie, 2, Pismo inspektora szkolnego Górskiego do Kuratorium Okręgu Szkolnego Szczecińskiego z 10.07.1946, k. 35.

${ }^{66}$ A. Kwilecki, Rola spoleczna nauczyciela..., s. 56.

${ }^{67}$ Ibidem. Por. L. Turek-Kwiatkowska, Nauczycielstwo Pomorza Zachodniego w latach 1945-1948, „Przegląd Zachodnio-Pomorski”, 1964, nr 4, s. 39.

${ }^{68}$ Por. E. J. Kryńska, S. Mauersberg, Indoktrynacja młodzieży szkolnej..., s. 171; K. Kosiński, Oficjalne i prywatne..., s. 27.

${ }^{69}$ AP w Koszalinie, Inspektorat szkolny Koszalin 1, Zestawienie danych liczbowych z projektów organizacyjnych $1950 \mathrm{r}$. 
Pomoc rodziców była także niezbędna przy zwożeniu drewna opałowego dla szkół, często pochodzącego z rozbiórek; remontach przeprowadzanych tzw. sposobem gospodarczym, a polegających na naprawie pieców, malowaniu sal i naprawie dachów ${ }^{70}$.

We wszystkich placówkach zorganizowano dożywianie w postaci kawy i chleba, ewentualnie mleka, dzięki zasiłkom otrzymywanym z Inspektoratu Oświaty w Koszalinie. Do zakupu tych ostatnich przyczyniali się także rodzice płacący składki na koła rodzicielskie (szkolne komitety rodzicielskie i opiekuńcze) oraz urządzający na tę rzecz zabawy dobroczynne. To także z ich funduszy w tym okresie opłacano pensje woźnych i palaczy, np. woźnej w Będzinie płacono pensję ok. 200 złł11.

Nauczyciele i uczniowie odwdzięczali się, urządzając akademie i poranki. Przetrwały zapisy o uroczystościach w szkole w Sarbinowie. Były to szkolne mikołajki, zorganizowane 26 grudnia 1945 r. Przy własnoręcznie zbudowanym żłóbku i ustawionej choince dzieci odśpiewały kolędy oraz przedstawiły dwa skecze - „Kasia” i „Maria”. Następnie od świętego Mikołaja otrzymały prezenty i łakocie, zakupione przez nauczycielkę za 700 zł zebrane wcześniej wśród rodziców. Całość zakończyła wspólna zabawa ${ }^{72}$. Z okazji rocznicy wyzwolenia Warszawy, 20 stycznia 1946 r. o godz. 17.00 w Sarbinowie Melania Grodzicka zorganizowała oficjalną akademię: odśpiewano hymn, Rotę, dzieci deklamowały patriotyczne wiersze, zebrano $300 \mathrm{zł}$ na odbudowę Warszawy ${ }^{73}$. Podobny przebieg miały uroczystości i w innych placówkach. Obchodzono uroczystości związane z rocznicą wybuchu II wojny światowej, w 1946 r. z okazji 3 Maja - święta Najświętszej Marii Królowej Polski i Święta Konstytucji, być może Dzień Kobiet (od 8 marca 1946). W takich dniach w szkołach odwoływano zajęcia, zbierała się młodzież i miejscowa ludność, by wysłuchać wierszy i pieśni patriotyczno-religijnych. W ten sposób szkoły stawały się lokalnymi centrami kultury. Zapewne w pierwszych latach po wojnie (do 1948) urządzano wigilijki szkolne (w ostatnim dniu nauki przed feriami świątecznymi - dzielono się wtedy opłatkiem, śpiewano kolędy, otrzymywano słodycze) oraz święto odzyskania niepodległości w 1918 r. (11 listopada).

Powyższy harmonogram uroczystości, za wyjątkiem 1 września, 17 stycznia i 8 marca, był nie do zaakceptowania przez komunistyczne władze. Musiał nastąpić proces - jak to określano - laicyzowania mas ludowych - likwidacji wpływów Kościoła. W październiku 1948 r. zainicjowano miesiąc ,pogłębiania przyjaźni polsko-radzieckiej”. W związku z tym Ministerstwo Oświaty zarządziło przeprowadzenie we wszystkich szkołach cyklu pogadanek, w czasie których należało podkreślać rozstrzygające znaczenie Związku Radzieckiego w odzyskaniu i utrwalaniu niepodległości. Dyrekcje szkół zostały zobowiązane do organizowania wycieczek na okolicznościowe wystawy urządzane przez TPPR. Angażowano również organizacje młodzieżowe działające w szkołach do uporządkowania grobów radzieckich. Dla podkreślenia „społecznych i politycznych warto-

\footnotetext{
${ }^{70}$ AP w Koszalinie, Gm. Będzino 8, Protokół z sesji GRN z dnia 3.04.1952, k. 89.

71 Decyzję o zatrudnieniu w szkołach etatowych woźnych radni gminy Będzino podjęli dopiero 29.10.1947 AP w Koszalinie, Gm. Będzino 2, Protokół z zebrania GRN z dnia 29.10.1947, k. 14.

72 ASPwS, Kronika.

73 Ibidem.
} 
ści" filmu radzieckiego zorganizowano festiwale filmów radzieckich i przeglądy starych filmów we wszystkich większych miastach Polski. W szkołach należało urządzić kąciki filmu radzieckiego, na których promowano aktorów radzieckich. Do pracy agitacyjnej włączono także kina objazdowe. Zwieńczeniem obchodów stały się organizowane na terenie szkół akademie i pogadanki na temat rewolucji październikowej ${ }^{74}$. Nie ocalały żadne dokumenty przedstawiające realizację zaleceń na terenie gminy Będzino, można jednak przypuszczać, że również tu znalazły się jakieś radzieckie akcenty. Ukoronowaniem miesiąca były obchody Wielkiej Socjalistycznej Rewolucji Październikowej 7 listopada.

Decydujące zmiany zaszły w 1949 r. W maju po raz pierwszy obchodzono Święto 1 Maja, którego uroczystości kontynuowano i w latach kolejnych. Miały kształt akademii, a udział uczniów był w niej obowiązkowy ${ }^{75}$. Przykładowo w 1950 r. w Sarbinowie akademię zorganizowano w sali Funduszu Wczasów Pracowniczych „Przodownik”. Po licznych oficjalnych przemówieniach, dzieci zaprezentowały wiersze, piosenki i dwa przedstawienia: „Współzawodnictwo” i „Cztery córy miał tata”. W kolejnych latach recytowano także po rosyjsku ${ }^{76}$. Od tego roku być może obchodzono również inne uroczystości, np. urodziny Włodzimierza Lenina (22 kwietnia 1949), Międzynarodowy Dzień Pokoju (od 3 października 1949 r.), urodziny Józefa Stalina (21 grudnia w latach 1948-1952). W specjalnie przygotowanej instrukcji Ministerstwo Oświaty poleciło wykorzystać zajęcia lekcyjne do głębszego zaznajomienia młodzieży z życiem i działalnością J. Stalina, jak go wówczas określano - wielkiego wychowawcy postępowej młodzieży, przyjaciela dzieci, opiekuna różnych organizacji mających na celu propagowanie partii. We wszystkich klasach należało wygłosić pogadanki o Stalinie, przy czym zalecano, aby forma wygłoszenia była prosta, bezpośrednia i mobilizujaca młodzież uczuciowo ${ }^{77}$.

W miejsce wigilijek szkolnych wprowadzono tzw. choinki noworoczne (zawsze po Bożym Narodzeniu), w czasie których prezenty przynosił już nie Święty Mikołaj, ale tzw. Dziadek Mróz ${ }^{78}$ lub w ostateczności gwiazdor. Zalecano, aby w czasie tych uroczystości podkreślać wspaniałe osiagnięcia zrealizowanego planu trzyletniego oraz omówić zapoczątkowanie nowego historycznie doniosłego okresu, tzw. planu 6-letniego, w którym to zbudowane zostaną w naszym kraju podstawy socjalistycznego ustroju. Treści każdej imprezy noworocznej musiały uwzględniać dotychczasowy dorobek klasy robotniczej oraz zapał, z jakim klasa robotniczo-chłopska przystępuje do planu 6-letniego ${ }^{79}$.

Od 1 czerwca 1950 r. zaczęto obchodzić Dzień Dziecka. W lutym 1952 r. odbyły się obchody ku czci Armii Radzieckiej, pod hasłem „Pogromcy faszyzmu oraz obrońcy po-

\footnotetext{
${ }^{74}$ L. Szuba, Polityka oświatowa państwa ..., s. 163. K. Kosiński (Oficjalne i prywatne..., s. 163) sugeruje, że obchody miesiąca pogłębiania przyjaźni polsko-radzieckiej zainicjowano od $1949 \mathrm{r}$.

${ }^{75}$ AP w Koszalinie, Gm. Będzino 4, Protokół z zebrania GRN z dnia 27.04.1949, k. 15. Por. K. Kosiński, Oficjalne i prywatne..., s. 161.

${ }^{76}$ ASPwS, Kronika.

77 K. Kosiński, Oficjalne i prywatne..., s. 180.

78 ASPwS, Kronika.

79 Szerzej zob. K. Kosiński, Oficjalne i prywatne..., s. 162-168.
} 
koju" - deklamowano wiersze i śpiewano pieśni. Wielkim echem odbiła się śmierć Józefa Stalina 5 marca 1953 r. Szkoły zobowiązano do uczczenia go minutą ciszy, do sporządzenia okolicznościowych gazetek ściennych, gdzie obowiązkowo musiał zawisnąć portret zmarłego przepasany kirem ${ }^{80}$.

Tradycyjnie uroczystą oprawę miało także zakończenie roku szkolnego. Najlepsi uczniowie otrzymywali książki ufundowane przez Komitety Rodziców. Rodzice uczniów kończących szkołę na zakończenie organizowali przyjęcie, przynosili ciasta, słodycze urządzali zabawę przy muzyce ${ }^{81}$.

Przez cały analizowany okres miały miejsce akcje propagandowe o wydźwięku wychowawczym, które polegały na moralnym i rzeczowym wspomaganiu dzieci z „,bratnich krajów”, m.in. Korei Północnej, Wietnamu i NRD. Odbywały się również „masówki”, a wśród nich potępiająca Anglię, za krytyczne podsumowanie Światowego Kongresu Obrońców Pokoju (listopad 1950 r.).

Zapewne i będzińscy nauczycieli zmuszeni byli brać udział w organizowaniu referendum 1946 r. i w wyborach do sejmu 1947 i 1952 roku $^{82}$. W zasadzie nie było inicjatyw kulturalnych, politycznych czy gospodarczych, w których nauczyciele nie braliby czynnego udziału. Manifestująca swą radość młodzież stała się nieodzownym elementem każdej uroczystości państwowej. Odtąd uczniowie i nauczycieli zobligowani byli wtedy do udziału we wszystkich ogólnopolskich akcjach, takich jak akcja wykopkowa czy omłotowa $^{83}$. Nauczyciele zajmowali się także organizowaniem pomocy sąsiedzkiej, rozdzielaniem darów dla najbiedniejszych, brali także udział w zwalczaniu chorób i patologii społecznych $^{84}$.

Najważniejszą zdaje się prowadzona akcja likwidacji analfabetyzmu. Gminna Rada Narodowa (GRN) w Będzinie już 5 października 1947 r. uchwaliła rozpoczęcie kursów nauczania początkowego dla analfabetów - przewodniczącym kursów wybrano radnego Józefa Biegańskiego, zastępcą Stanisława Łupinę. Oczywiście kursy prowadzili nauczyciele. Początkowo nie cieszyły się jednak większą popularnością. Tempa akcja nabrała od 1949 r., kiedy to sejm uchwalił 7 kwietnia ustawę o likwidacji analfabetyzmu ${ }^{85}$, zmuszającą osoby nieumiejące pisać i czytać do udziału w zajęciach szkolnych. Jednocześnie nauczycieli zobowiązano do prowadzenia zajęć dla analfabetów ${ }^{86}$. Każdy w wieku 14-50 lat podlegał sprawdzeniu umiejętności pisania i czytania. Miał w tym celu napisać podyktowane zdanie, np. miejsce urodzenia i zamieszkania, datę urodzenia słowami, do jakiej gminy i powiatu należy jego wieś itd., oraz przeczytać, nie głoskując prosty, napi-

${ }^{80}$ Por. T. Skonieczny, Z dziejów szkolnictwa..., s. 43.

81 Por. ASPwS, Kronika.

${ }^{82}$ W 1952 r. nauczyciele z Sarbinowa przeprowadzili dodatkowo 23 lekcje prezentując dzieciom i mieszkańcom sylwetki kandydatów na posłów i przekonując do wzięcia udziału w głosowaniu. Por. ASPwS, Kronika.

${ }^{83}$ AP w Koszalinie, Gm. Będzino 8, Protokół z sesji GRN z dnia 8.11.1951, k. 58.

${ }^{84}$ R. Fudali, Heteronomiczny charakter ról....

${ }^{85}$ DzU 1949, nr 25, poz. 177, Ustawa o likwidacji analfabetyzmu z dnia 7.04.1949 r.

${ }^{86}$ Ustawa o likwidacji analfabetyzmu z 7.04.1949 r. 
sany dużym drukiem tekst. Komu się to udało (napisać choćby z błędami ortograficznymi i w miarę płynnie przeczytać) był od nauki zwolniony ${ }^{87}$. Mimo że wielu mieszkańców gminy uważało naukę czytania i pisania za zbędne - ruszyło siedem kursów dla analfabetów. Opiekunami z ramienia GRN zostali m.in. radni: dla Będzinka - Stanisław Perzyński, Antoni Krawczyk dla Łekna, Stanisław Świątkowski - Sarbinowa, Antoni Janicki - Dobrego ${ }^{88} .23$ czerwca 1950 r. kilka osób z Chłopów i Sarbinowa ukończyło kurs III stopnia MO prowadzony przez Zygmunta Bloka, kierownika szkoły w Sarbinowie. Rangę egzaminów końcowych podnosiła obecność na nich wszystkich nauczycieli, kierownika szkoły w Będzinie, inspektora szkolnego PRN w Koszalinie i sekretarza POP w Sarbinowie ${ }^{89}$.

Podsumowując, w analizowanym okresie pomimo zmian politycznych zachodzących w kraju, niepopularnej na wsi decyzji o kolektywizacji rolnictwa, nauczyciele pozostali ważnymi postaciami wiejskiego życia, a szkoła wciąż postrzegana była jako specyficzna placówka kulturalna.

\section{Zakończenie}

Rozwój będzińskiego szkolnictwa uzależniony był od warunków ekonomicznych, politycznych i społecznych kraju, a także od ogólnych założeń polityki oświatowej państwa, dlatego też odbywał się na podobnych zasadach jak w innych, wiejskich rejonach kraju. Zgodnie z centralnymi wytycznymi następowała stopniowa ideologizacja szkolnictwa. Podobne były trudności spowodowane wojną i okupacją oraz nową sytuacją terytorialną i demograficzną. Nieustanne w pierwszych latach po wojnie ruchy migracyjne ludności komplikowały tworzenie sieci szkolnej, zmuszając administrację oświatową do nieustannych korekt. Również baza materialna, osiągnięcia organizacyjne, programowe, kadrowe, wychowawcze i dydaktyczne nie odbiegała zasadniczo od większości gmin na Ziemiach Zachodnich i Północnych.

87 T. Szrubka, Szkolnictwo koszalińskie w..., s. 138

${ }^{88}$ AP w Koszalinie, Gm. Będzino 5, Protokół z plenarnego posiedzenia GRN z dnia 11.05.1950, k. 22; Sprawozdanie Zarządu Gminnego z działalności za czas swego istnienia to jest od 1945 r. do 1950 miesiąca czerwca, k. 28.

${ }^{89}$ ASPwS, Kronika. 